\title{
Federal Taxation of Community Property
}

\author{
Harrop A. Freeman* and \\ Virginia Schwartz Mueller** \\ "Community is like a ship ...." \\ Henrik Ibsen.
}

One might imagine that Ibsen was going to finish his statement by referring to the ease with which anyone can rock the boat. He actually concludes: "every one ought to be prepared to take the helm." In a very real sense it is this ability of either husband or wife to "take the helm" at some time or in respect to some rights that gives rise to the peculiarities of tax law as applied to community property. This article is no attempt to plumb the rules of property law; these will be found reviewed elsewhere. It does seek to explore community property taxation in the light of more recent federal statutes, regulations and cases.

\section{I}

FEDERAL TAXATION OF COMMUNITY INCOME

SECTION 11 of the Internal Revenue Code provides that "there shall be levied, collected, and paid for each taxable year upon the net income of every individual a normal tax ...."1 Section 12(b) adds that "there shall be levied, collected, and paid for each taxable year upon the surtax net income of every individual ..." the surtax shown. ${ }^{2}$ A similar provision has been included in the federal income tax statutes since $1919 .^{3}$

Prior to 1930, the United States Treasury Department employed a variety of rulings concerning the income tax returns of spouses domiciled in a community property state. ${ }^{4}$ Some of the uncertainty

*Professor of Law and Secretary of the Cornell Law School; LL.B. 1930.

**LL.B., Cornell Law School, 1946.

1 I. R. C. $\$ 11$.

2Ibid. \$12(b).

${ }^{3}$ For the legislative history, see (1931) 31 CoL. L. Rev. 513 ; (1931) 5 Turane L. REv. 301.

4 T. D. 3071,3 Cusc. Burc. 221 ; T. D. 3138, 4 ibid. 238; O. D. 285, 1 ibid. 189; O. D. 426, 2 ibid. 198; Mim. 3723, VIII-1 ibid. 89; T.D. 3596, III-1 ibid. 101; T. D. 3670, IV-1 ibid. 19; Mim. 3201, III-1 ibid. 346; T. D. 3568, III-1 ibid. 84. 
was removed by five test cases $^{5}$ brought before the Supreme Court for a determination of two questions: first, whether under the applicable provisions of the Revenue Act of 1928 the entire community income of a husband and wife domiciled in Arizona, California, Louisiana, Texas, or Washington must be returned and the income tax thereon be paid by the husband; secondly, whether the wife has such an interest in the community income that she should separately report and pay a tax on one-half of such income. The Supreme Court determined the first question negatively and the second affirmatively.

Since the income tax was imposed on the income of every individual, the common meanimg of the expression as implying ownership was recognized. As under the community property laws of Arizona, California, Louisiana, Texas, and Washington, the wife is given ownership of one-half of the community property, the Court concluded that the income tax should be imposed on the wife's half of the community income. ${ }^{6}$ This amounts to giving spouses in a community property state advantages over noncommunity property state residents. The combined taxes of two spouses will often be no more than sixty per cent of the tax payable in noncommunity states. Furthermore, since domicile in a communal state carries the community property status to income and property acquired elsewhere, ${ }^{7}$ two salaries earned in a noncommunity property state may be taxed entirely differently.

Two attacks have been made on this discrepancy. One is to tax the income to the husband on the basis of management. ${ }^{8}$ It has been

5 Poe v. Seaborn (1930) 282 U. S. 101 (Wash.), (1931) 31 Cor. L. Rey. 513, (1931) 44 HaRv. L. Rev. 652, (1931) 5 Tulane L. Rev. 301; Goodell v. Koch (1930) 282 U.S. 118 (Ariz.); Hopkins v. Bacon (1930) 282 U.S. 122 (Tex.); Bender v. Pfaff (1930) 282 U.S. 127 (La.); United States v. Malcolm (1930) 282 U.S. 792 (Calif.); (1931) 1 IDAHO L. J. 180.

6 The importance of the state rules as to ownership can be seen in the California situation: under the California law as it stood prior to 1927 it was held in United States v. Rohbins (1926) 269 U.S. 315, that since "ownership" was in the husband he must report the income. See Sebree, Federal Taxation of Community Property (1934) 12 Tex. L. REv. 273; Nicholas, California Community Property and Federal Taxation Reexamined (1939) 14 CAL. ST. BAR. J. 9. In United States v. Malcolm (1930) 282 U. S. 792, the Court recognized the change wrought hy California Civil Code section 161a, effective July 29, 1927, and allowed separate returns of one-half the income to be filed. See also Bishop v. Comm'r (C.C.A. 9th, 1945) 152 F. (2d) 389.

7 Thus spouses domiciled in Washington were allowed to apply the Washington community property rules so as to allow each spouse to report for income tax one-half the salary of the husband earned in the Philippines. Sampson v. United States (N.D. Calif. 1945) 63 F. Supp. 624.

8 Hearlngs Before the Comamtiee of Ways and Means, on H.R. 8396, 73d 
said that the Court in the per curiam decision of Poe v. Seaborn," implied in a reference to Corliss v. Bowers, ${ }^{10}$ that "Congress might not declare the husband's rights of management to be ownership, but the court did not say that such rights could not be subjected to taxation as income." 11

The second approach is that of Professor Griswold. He asks, "would it be feasible to extend to all of the country the tax benefits of the community system without forcing the adoption of that system in fact?" 12 It has been suggested that this might be accomplished by requiring the husband and wife to file joint returns, but computing the tax as twice the tax on half the joint income, with the resulting total tax allocated to each in accordance with his contribution. ${ }^{13}$ The first suggestion would increase the federal income, the second would dissipate it.

Other alternatives suggest themselves: (1) income might be taxed to the person who earned it or in accordance with "scurce" in keeping with the interpretation of the word "of" as denying the right to shift income to one who did not produce it; ${ }^{14}(2)$ the spouses might be permitted to report and be taxed on one-half of the income but at a rate producing a tax on each equal to one-half the tax had they filed a joint return. This proposal is open to the charge of a discriminatory tax rate but might be sustained as a compensating rate.

No system based on an election to come under the community

Cong. 2d Sess. (1934) ; Paul, The Background of the Revenue Act of 1937 (1937) 5 U. of Chi. L. Rev. 41, 84-5; Green, Theory and Practice of Modern Taxation (1938) 51.

9 (1930) 282 U.S. 101.

10 (1930) 281 U.S. 376.

11 Altman, The Community Property Amendments to the Estate Tax Law (1943) 21 TAX MAG. 643.

12 Griswold, Cases and Materiajs on Federal Taxation (1940) 427.

13 Altman, Community Property; Avoiding Avoidance by Adoption in the Revenue Act (1938) 16 TAX MAG. 138.

14 Jones v. Page (C.C.A. 5th, 1939) 102 F. (2d) 144, cert. den., (1939) 308 U.S. 562. Some precedent can be found for taxing income to the spouse who in fact earns it in the ruling and decisions giving effect for tax purposes to the husband and wife's agreement under California law that the earnings of each shall be his separate property. G. C. M. 18884, 1937-2 Cum: Bulz. 58; Van Dyke v. Comm'r (C.C.A. 9th, 1941) 120 F. (2d) 945 ; P. C. Jurs, Memo T. C., (Aug. 20, 1943) aff'd., (C.C.A. 9th, 1945) 147 F. (2d) 805. There is some support for the taxing of income to the person earning it at least where the parties have made agreements allocating the income to the one earning it; see the separation agreement cases typical of which are: Muriel Oakes Ames (1934) 30 B. T. A. 516; Van Every v. Comm'r (C.C.A. 9th, 1940) 108 F. (2d) 650, cert. den., (1940) 309 U.S. 689; Sparkman v. Comm'r (C.C.A. 9th, 1940) 112 F. (2d) 774; William L. E. O’Brien (1943) 1 T. C. 1137, aff'd., (C.C.A. 9th, 1945) 148 F. (2d) 456. 
property rules would seem to stand the test. In a series of cases the Tax Court permitted husband and wife to each report half the income under the Oklahoma statute of 1939 granting the election to come under communal property rules or not. ${ }^{1 \bar{s}}$ But in 1944 the Supreme Court held that federal taxing authorities were not bound by the state law since in effect the election was merely an anticipatory assignment of income. ${ }^{16}$ Thereupon the Oklahoma law was' repealed and the cases reversed. Many of the vagaries of community property income taxation have no pertinency to our present discussion..$^{17}$

None of the above suggestions fully answers the problem, for income taxation is inextricably tied up with estate and gift taxation and the rules there applied to community property. Some explanation or justification for the anomalous income tax position may be found in the estate tax treatment.

II

\section{FEDERAL ESTATE TAXATION OF COMMUNITY PROPERTY}

It is generally recognized that the federal estate tax embodies at least four bases of taxation: (1) ownership at death, (2) transfer by death, (3) termination of power of disposition or control, (4) barring of rights or interests of decedent thereby "ripening" or "enlarging" the rights or interests of others. No one of these can be relied upon predominately; each may be the basis of taxation. Ownership has become perhaps least essential. The trend in federal estate taxation has been to tax not only transfers at death but the creation or relinquishment of any power or privilege which is an incident to the ownership of property when this creation or relinquishment is occa-

15 Thomas A. Creekmore, $\$ 42,611$ P.H. memo T.C.; L.W. Prunty, $\$ 42,635$ P.H. memo T. C.; J. A. LaFortune, $\$ 42,631$ P.H. memo T. C.; Armais Arutunoff, $\S 42,636$ P. H. memo T. C.; Charles L. Yancey, $\$ 42,637$ P. H. memo T. C.

16 Comm'r v. Harmon (1944) 323 U.S. 44.

17 The rule requiring deductions to be divided in the same proportion as income is equitable, Stewart v. Comm'r (C.C.A. 5th, 1938) $95 \mathrm{~F}$. (2d) 821 ; the rules as to the difference between income received from services and from property are barely comprehensible, G. C.M. 13742, XIII-2 CuM. BunL. 181, Dolores Crabb (1940) 41 B.T.A. 686, aff'd., (C.C.A.5th, 1941) 119 F. (2d) 772 ; the fine distinction as to proration of income, C. J. Wrightsman (1939) 40 B.T.A. 520, affd, (C.C.A. 5th, 1940) 111 F. (2d) 227. Fooshe v. Comm'r (C.C.A. 9th, 1942) 132 F. (2d) 686; the treatment of exempt income of the husband as being exempt in case of both husband and wife, $\mathrm{E}$. R. Kaufman (1928) 9 B.T.A. 1180, I.T. 3665, 1944 Cur. Bunt. 161; and the treatment of amounts earned during marriage but received after death of one of the spouses, John $M$. King (1932) 26 B.T.A. 1158, af'd, (C.C.A.5th, 1934) 69 F. (2d) 639 , will continue to vex tax practitioners. 
sioned by death. ${ }^{18}$ The Supreme Court has sustained the application of estate taxes upon the death of one of the owners of the property held in joint ownership, measured by the full value of the property so held. ${ }^{19}$

It is interesting before examining the estate taxation of community property to review briefly the history of estate taxation of joint tenancies and tenancies by the entireties. The first attempt to tax any part of these in the estate of either tenant was by the Revenue Act of 1916. This was held not to be retroactive to tenancies vested prior to September $8,1916 .{ }^{20}$ It was first considered that only onehalf the value of the property should be included in the decedent's estate, ${ }^{21}$ if the tenancy was created prior to 1916 and death occurred before 1924, though there was considerable pressure to tax the whole amount, ${ }^{22}$ and the power to tax the full amount was easily found by the Supreme Court where the tenancy was created after $1916 .^{23}$ The Revenue Act of 1924 expressly made applicable to previously created tenancies the provisions including joint tenancies and tenancies by the entireties in the estate of the deceased tenant unless the other produced proof of his or her separate contribution and under this the courts upheld the inclusion of the total value even though the tenancy was created prior to $1916 .^{24}$

18 Tyler v. United States (1930) 281 U.S. 497; United States v. Jacobs (1939) 306 U.S. 363.

19 Ibid.

20 Knox v. McElligott (1922) 258 U.S. 546.

21 Gwinn v. Comm'r (1933) 287 U.S. 224; Griswold v. Helvering (1933) 290 U.S.

56; Whitehead v. Comm'r (1933) 64 F. (2d) 118, cert. den., (1933) 290 U.S. 690.

22 Thomas Stephenson (1933) 27 B. T. A. 850; Goodenough v. Comm'r (C.C.A. 6th, 1936) 83 F. (2d) 389.

23 Tyler v. United States, supra note 18.

24 Phillips v. Dime Trust \& Safe Deposit Co. (1931) 284 U.S. 160; Third National Bank and Trust Co. v. White (1932) 287 U. S. 577; Foster v. Comm'r (1938) 303 U.S. 618, reh'g den., (1938) 303 U.S. 667; United States v. Jacobs (1939) 306 U.S. 363. This in spite of the provisions of U.S. Treas. Reg. 80 (1937) art. 23: "(4) If the property was acquired by the decedent and his or her surviving spouse as tenants by the entirety by gift, will, or inheritance, then but one-half of the property becomes a part of the gross estate. (5) If acquired by the decedent and the other joint owner as joint tenants by gift, will, or inheritance, and their interests are not otherwise specified or fixed by law, then one-half only of the property is a part of the gross estate ..." which was amended by T.D. 5239, 1943 Cum. BunL. 1081, 1085 (Reg. 105, $\$ 81.22$ ) to read: "Taxable portion.-The entire property is prima facie a part of the decedent's gross estate. But it is not the intent of the statute that there should be so imcluded a greater part or proportion thereof than is represented by an outlay of funds, which, in the first instance, were decedent's own, or more than a fractional part equal to that of the other joint owner should neither have parted with any consideration in its acquirement." 
Since there was no specific statutory provision or regulation governing the federal estate taxation of community property and any attempt to bring its inclusion under the joint tenancy and tenancy by the entirety provision failed, ${ }^{25}$ taxation became a question of the interest in the property which the decedent had at the date of death, thus bringing taxation under the general provision of the Internal Revenue Code section 811 (a) rather than the specific provisions of section 811 (c) to (e). This resulted in as many different rules as there were community property states. The community property laws of most states were considered as creating such estates in both the husband and wife as to permit the inclusion of only one-half the property in each estate. ${ }^{26}$ Wardell $v$. Blum ${ }^{27}$ in 1921 applied this rule to California. In 1926 the California supreme court in Stewart v. Stewart ${ }^{2 s}$ ruled that the husband was the owner of California community property. Thereupon the federal courts determined that all California community property was to be included in the husband's estate for federal estate tax purposes. ${ }^{29}$ In 1927 the California legislature ${ }^{30}$ specifically confirmed the wife's right to one-half of the community property; hence a return to Wardell v. Blum was in order. Louisiana's peculiar rule of life usufruct resulted in total inclusion. ${ }^{31}$

This unsatisfactory state of affairs led, in 1942, to the adoption of two amendments to the Internal Revenue Code and to the amendment of the regulations accordingly. ${ }^{32}$

25 Hernandez v. Becker (C.C.A. 10th, 1931) 54 F. (2d) 542.

26 G. C. M. 7773, IX-2 Cuss. Buls. 426 (Tex.); Stewart v. Comm'r (C.C.A. 5th, 1933) 63 F. (2d) 62 (Tex.) ; Estate of Edward Sweeney (1929) 15 B. T. A. 1287 (Wash.); Estate of Frederick Broadbent (1930) 20 B.T.A. 890 (Wash.); Pacific National Bank of Seattle (1939) 40 B.T.A. 128, acq. by Comm. (Wash.); Wardell v. Blum (C.C.A. 9th, 1921) 276 Fed. 226, cert. den., (1921) 258 U.S. 617 (Calif.).

27 (C.C.A. 9th, 1921) 276 Fed. 226, cert. den., (1922) 258 U.S. 617.

28 (1926) 198 Cal. 318, 249 Pac. 197.

29 T. D. 3138, 4 Cum. BuLc. 238; T. D. 3891, V-2 ibid. 232; Talcott v. United States (C.C.A. 9th, 1928) 23 F. (2d) 897, cert. den., (1928) 277 U.S. 604; Gump v. Comm'r (1940) 42 B.T.A. 197.

30 CaL. Civ. Code $\S 161$, effective July 29, 1927.

31 Liebman v. Fontenot (W.D.La. 1921) 275 Fed. 688; Beals v. Fontenot (C.C.A. 5th, 1940) 111 F. (2d) 956.

32I. R. C. $\$ 811$ (e) (2): "Community interests. To the extent of the interest therein held as community property hy the decedent and surviving spouse under the law of any State, Territory, or possession of the United States, or any foreign country, except such part thereof as may be shown to have heen received as compensation for personal services actually rendered hy the surviving spouse or derived originally from such compensation or from separate property of the surviving spouse. In no case shall such interest included 
The 1945 companion cases of Fernander v. Wiener ${ }^{33}$ and United States v. Rompel ${ }^{34}$ determine the constitutionality of the 1942 amendments to the federal estate tax..$^{35}$ The Fernandez $v$. Wiener opinion devoted over a page to the consideration of the Louisiana community property system. The limited nature of the wife's remedy should the husband make any alienation of property to her injury is noted..$^{3 e}$

The Rompel opinion does not delve into the details of the Texas community property system. Undoubtedly the language used is intentionally broad-Fernandez $v$. Wiener is not to be confined to Louisiana community property.

in the gross estate of the decedent be less than the value of such part of the community property as was subject to the decedent's power of testamentary disposition."

Regulations 105, § 81.23 [as amended by T. D. 5239, 1943 Cunr. Bur.. 1081, 1085]. Community Property. "In the case of estates of decedents dying after October 21, 1942, the gross estate includes the entire community property held by the decedent and surviving spouse under the law of any State, Territory, or possession of the United States or any foreign country, except such part thereof as may be shown to have been received as compensation for personal services actually rendered by the spouse or derived originally from such compensation or from separate property of the spouse. Section 811 (e) (2) also provides that in no case shall such interest included in the gross estate of the decedent be less than the value of such part of the community property as was subject to the decedent's power of testamentary disposition.

"Property derived originally from compensation for personal services actually rendered by the spouse or from separate property of the spouse includes property that may be identified as ( 1 ) income yiclded by property received as such compensation or by such separate property, and (2) property clearly traceable (by reason of acquisition in exchange, or othcr derivation) to property received as such compensation, to such separate property, or to such income. The rule established by this statute for apportioning the respective contributions of the spouses is applicable regardless of varying local rules of apportionment, and State presumptions are not operative against the Commissioner. The burden of identifying the property which may be excluded from the community interest rests upon the executor."

I. R. C. $\$ 827:$ "(b) Ijability of Transferee, etc. If the tax herein imposed is not paid when due, then the spouse, transferee, trustee, surviving tenant, . . or beneficiary, who receives, or has on the date of the decedent's death, property included in the gross estate under section $811(\mathrm{~b}),(\mathrm{c}),(\mathrm{d}),(\mathrm{e}),(\mathrm{f})$, or $(\mathrm{g})$, to the extent of the value, at the time of the decedent's death, of such property, shall be personally liable for such tax. Any part of such property sold by such spouse, transferee, trustee, surviving tenant, . . . or beneficiary, to a bona fide purchaser for an adequate and full consideration in money or money's worth shall be divested of the lien provided in section $827(\mathrm{a})$ and a like lien shall then attach to all the property of such spouse, transferee, trustee, surviving tenant, -... or heneficiary, except any part sold to a bona fide purchaser for an adequate and full consideration in money or money's wortlı."

33 (1945) ........ U.S. ......., 66 S. Ct. 178, rev'g (E.D. La. 1945) 60 F. Supp. 169.

35 I. R. C. $\S 811$ (e), amended by Revenue Act of $1942 \S 402$.

36 (1945) ........ U.S. ........, 66 S. Ct. 178, 183; LA. Crv. Code (Dart, 1945) art. 2404. 
In the Fernandez case, the Supreme Court promulgates the fol10wing principles:

"... Congress has a wide latitude in the selection of objects of taxation ... and even under the equal protection clause of the Fourteenth Amendment, which was not included in the Fifth, the states may distinguish, for purposes of transfer taxes, between property which has borne its fair share of the tax burdens and similar or like property passing to the same class of beneficiaries which has not." 3 i

"... the power of Congress to impose death taxes is not limited to the taxation of transfers at death. It extends to the creation, exercise, acquisition, or relinquishment of any power or legal privilege which is incident to the ownership of property, and when any of these is occasioned by death, it may as readily be the subject of the federal tax as the transfer of the property at death.

"... this Court has consistently sustained the application of estate taxes upon the death of one of the joint owners to property held in joint ownership, measured by the full value of the property so held." 38

The arguments that section 811 (e)(2) was unconstitutional are brushed aside as follows:

"Since the levy is an excise and not a property tax, the case is not one of taking the survivor's property to pay the tax on decedent's estate. As the tax is upon the surrender of old incidents of property by the decedent and the acquisition of new by the survivor, it is appropriately measured by the value of the property to which these incidents attach. The tax burden thus laid is not so unrelated to the privileges enjoyed by the taxpayers who are owners of the property affected that it can be said to be an arbitrary exercise of the taxing power." 39

". . . the uniformity in excise taxes exacted by the Constitution is geographical uniformity ....

"Appellees suggest that interests in tenancies in common and limited partnerships are very like interests in community property, and that if the tax is to be uniform, the one cannot be taxed unless the other is also. But even if it be as appellees argue ... we find no lack of uniformity in the constitutional sense." 10

37 Fernandez v. Wiener, supra note 33, at 184.

38 Ibid. at 184, 185. In this connection the Court refers to Tyler v. United States (1930) 281 U.S. 497 and United States v. Jacobs (1939) 306 U.S. 363.

39 Supra note 33 , at 187.

40 Ibid. at 188. The Court made no reference to section 827 (b) the plain import of which is to place the surviving wife in the position of being personally liable for the tax levied on the entire community property although only one-half of the counmunity property was subject to the testamentary disposition of the husband, but it did comment as 
The application of these general principles to the federal estate taxation of the interests in community property leads the Court to reconsider the effect of the death of either spouse in the marital community. It becomes apparent that the surviving wife is to be taxed for the benefit she received when "she loses the business manager that she voluntarily selected by the marriage contract." 41 In the language of the Court, the husband's death "terminates his expansive and sometimes profitable control over the wife's share, and for the first time brings her half of the property into her full and exclusive possession, control and enjoyment." 42 And what benefit does the husband receive when his wife dies? The Court answers that "her death, by ending the marital community, liberates her husband's share from the restrictions which the existence of the community had placed upon his control of it." 43

The Rompel case contains a somewhat similar answer:

"[The Texas] laws governing community property interests are similar in most respects to those of Louisiana described in our opinion in the Wiener case, supra. On the death of the husband, in Texas, as in Louisiana, the wife's share of the community is freed from the restrictions of his exclusive management and control, and the wife acquires exclusive possession and enjoyment of the property constituting her share, as well as important new powers of control and disposition over it. On the death of the wife, her share passes to her heirs, and his share is freed from the limitations which the existence of the community places on his control of community property." 44

Section $811(\mathrm{e})(2)$ having been held constitutional in the Wiener and Rompel cases, the cessation of the husband's management and

follows: "The revenue laws make no provision for the distribution of the burden of the tax beyond providing that the tax shall be a lien on all of the property included in the decedent's gross estate. [Citing I. R. C. $\$ 827$ (a) and referring to Detroit Bank v. United States (1943) 317 U.S. 329, 331-333.] Section 826(b) of the Internal Revenue Code ... contemplates that the tax 'be paid out of the (taxable) estate before its distribution,' unless otherwise directed by decedent's will. Although the share of the surviving spouse is subject to the hen and the tax must be paid out of the estate as a whole, the federal statute leaves it to the states to determine how the tax burden shall be distributed among those who share in the taxed estate." [Citing Riggs v. Del Drago (1942) 317 U.S. 95.] If the community property states are to determine how the tax burden shall he distributed can the effect of section 827 (b) be circumvented by the legislatures of Arizona, California, Idaho, Louisiana, Nevada, New Mexico, Texas, and Washington?

11 Aberle, Federal Taxalion of Comsmunity Properly (1944) 19 IDAmo ST. BAR J. $101,105$.

42 Fernandez v. Wiener, supra note 33 , at 186.

43 Ibid.

44 United States v. Rompel, supra note 34, at 192. 
control over his wife's half of the community property has been upheld as the occasion for the federal estate tax if he dies first. A different right, i.e., the wife's testamentary power of disposition, is made the occasion for the tax if she should die first, under the provision that, "In no case shall such interest included in the gross estate of the decedent be less than the value of such part of the community property as was subject to the decedent's power of testamentary disposition." ${ }^{45}$ Thus the wife's half of the community property will be included in her husband's gross estate and in her gross estate.

If Mrs. Wiener should die within five years after the death of her husband, will she be entitled to the provisions of section 812 (c) allowing a deduction from the gross estate of "an amount equal to the value of any property (1) forming a part of the gross estate situated in the United States of any person who died within five years prior to the death of the decedent, or (2) transferred to the decedent by gift within five years prior to his death, where such property can be identified as having been received by the decedent from the donor by gift, or from such prior decedent by gift, bequest, devise, or inheritance ..."? $?^{46}$ Since the surviving spouse has a vested interest from the moment of acquisition of community property, it might be said that nothing passes from the deceased spouse to the survivor by gift, devise or inheritance. It is submitted that a deduction be given by virtue of the husband's estate bearing the tax on the surviving wife's half interest. This could be done (a) by applying the interpretation already given "inheritance" in certain survivorship cases ${ }^{4 i}$ that property received by right of survivorship is received through "inheritance" or (b) the clause beginning "where such property can be identified" and ending "devise or inheritance" could be held not to modify the first provision "forming a part ... prior to the death of the decedent."

It is submitted that the statute and cases leave many important points still undecided. Section 811 (e)(2) provides for the inclusion in the gross estate of community property "except such part thereof as may be shown to have been received as compensation for personal services actually rendered by the surviving spouse or derived originally from such compensation or from separate property of the sur-

45 Supra note 32.

48 I. R. C. $\$ 812$ (c), as amended by Revenue Act of $1942 \S 407$ (a) (1).

17 Comm'r v. Fletcher Sav. and Trust Co. (C.C.A.7th, 1932) 59 F. (2d) 508. 
viving spouse." 48 This provision may be quite satisfactory when applied to joint and survivorship property and totally inept as to community property where the income theory is that the community income derives from the efforts of each and is to be taxed one-half to each accordingly. Obviously the burden of making the showing of the source of compensation will be upon the deceased's survivors. Congress has neglected to consider that some of the community property may not have been received as compensation for services rendered, such as money borrowed on an unsecured promissory note. Such community property may be included either in the husband's estate or in the wife's estate depending on which spouse dies first. An illustration of this situation is given by a Texas lawyer:

"If the husband or the wife should purchase stock through the creation of a community debt and this debt is paid off with dividends from such stock, these dividends being in Texas, such stock is not derived originally from compensation for services rendered by either spouse. Nor is it derived from the separate property of either spouse. Therefore the interest of both spouses in such stock would be included in the estate of the wife should she die first. The husband is taxed on his wife's share as well as on his own at his prior death, and the wife is taxed on her husband's share as well as on her own at her prior death. $100 \%$ of the property is thus regarded as [belonging to] each, and the tax is laid on $100 \%$ without regard to ownership, and dependent solely on the sheer accident of who dies first." 49

Further, although the wife's estate is taxed on both halves of the community property she has no testamentary power of disposition over her husband's half. Nothing happens at her death with respect to his half, yet she is taxed thereon. At his later death, his half will bear a second tax. Thus the community estate may be taxed 150 per cent at the death of the husband and wife. In this respect community property is at a disadvantage compared to joint or entirety tenancies -apparently without logical reason.

The Internal Revenue Code provides for an adjusted basis for determining gain or loss for income tax purposes. Section 113 (a) (5) states that "If. the property was acquired by bequest, devise, or inheritance, or by the decedent's estate from the decedent, the basis shall be the fair market value of such property at the time of such

4s Supra note 32.

49 Jackson, New Federal Estate and Gift Taxes on Cormmunily Property (1943) 21 Tax Mao. 535, 536. 
acquisition." ${ }^{50}$ Where community property is sold after the death of one of the spouses, the decedent's half interest in the community property carries as its basis in the hands of his estate the fair market value at date of death. Thus no income tax would result from the sale of this half interest. Where the surviving spouse's half interest is sold, the basis of that half is cost. The curious result has been pointed out that whereas both halves of the community are taxed at the date of death of the husband, a sale thereafter requires the use of the value at date of death as to half of the property, and original cost as the basis of the other half..$^{51}$

Suppose that the husband creates a testamentary trust of the community property giving the wife the income for her life, with the remainder to their children. The Treasury Department has held that where the wife elects to take under the will she has made a taxable exchange of her interest in the community property for the rights given to her by the will:

"Value of her life interest under the terms of the will is commuted to present worth by the use of mortality tables and a $4 \%$ discount factor. Where the value of her property permitted by her to go under the terms of the will exceeds the present worth of her life income under the will, the Treasury holds that her election constitutes a gift from her to the remaindermen, to the extent of the difference between such values and that such gift is subject to gift taxes."

Although the entire community property is subject to the estate tax at the husband's death, should the wife elect to take under a will of the type referred to, a few days later would a gift tax be exacted from her with respect to identical property?

"Treasury for years has taken the position that where the wife elects
under such circumstances and receives an annuity or life mcoine
under her husband's will, she has in effect created a trust with respect
to her interest in the community property by adopting the will and
thus she has created a trust retaining life mcome, and at her death
an estate tax is to be laid on the value of her community interest in
the hands of the husband's trustees."

At the husband's death, the entire community property nuay be subject to the estate tax under section 811 (e)(2). When the wife elects

60 I. R. C. $\$ 113$ (a) (5).

B1 Jackson, op. cit. supra note 49 , at 537 .

62 Ibid. at 538.

6 Ibid. 
to take under her husband's will a gift tax may be imposed on part of the same property under section 1000 (d). At the wife's death, an estate tax may again be collected on her share of the community property held by her husband's trustees under section 811 (c).

Section 811 (d) (5) provides that for the purpose of the contemplation of death provisions "a transfer of property held as community property by the decedent and surviving spouse under the law of any State, Territory, or possession of the United States, or any foreign country, shall be considered to have been made by the decedent, except such part thereof as may be shown to have been received as compensation for personal services actually rendered by the surviving spouse or derived originally from such compensation or from separate property of the surviving spouse." ${ }^{54}$ If the wife should die following the making of a gift of community property, the gift, under the contemplation of death provision, will be considered to have been made by her, although when the gift was made it was considered to have been made by the husband for gift tax purposes.

Yet, all nonmarital common law forms of ownership are possible in the community property states and husband and wife may hold property as tenants in common or as joint tenants. ${ }^{55}$ Regulations 105 , section 81.15 treats a transfer of community property, to the husband and wife as joint tenants when the wife is about to die, as being made by the surviving spouse and not by the deceased wife, ${ }^{58}$ hence the property would not be included in her gross estate as a transfer made by her in contemplation of death. Whether property is held in community or in joint tenancy, if the husband dies first, all of it is includible in his gross estate. If the wife dies first, half of the property held in community is includible in her gross estate, but no part of property held in joint tenancy would be includible. ${ }^{57}$

It would appear that considerable clarification of community property taxation is required. Although for income tax purposes those having communal interests may have an advantage over those who do not, it is doubtful whether this justifies the great discrepancy for estate tax purposes between communal and other husband-wife survivorship property.

54 I. R. C. $\$ 811$ (d) (5), as amended by Revenue Act of $1942 \S 402$ (a).

65 E.g., CAL. Crv. Code $\$ 161$; Siberell v. Siberell (1932) 214 Cal. 767, 7 P. (2d) 1003.

56 U.S. Treas. Reg. 105, \$81.15. See Taylor, Comments on the Federal Estate and Gift Tax Provision re Community Property (1944) 19 CAL. ST. BAR J. 106.

oT U. S. Treas. Reg. $105, \$ 81.22$. 


\section{III}

\section{FEDERAL TAXATION OF GIFTS OF COMMUNITY PROPERTY}

When we treat of gift taxation as related to community property"s we must differentiate between transfers prior to January 1,1943 and those made subsequently.

Prior to 1943 the question of on whom the gift tax fell was dependent upon the state community property laws. Thus, in general, the communal property being considered to belong to the husband and wife equally was, upon gift, taxable to the extent of one-half to each. Yet, prior to 1927 , since the husband was deemed to have the full property in Califorria, a gift from husband to wife was held to be taxable to the husband to the extent of the full value. ${ }^{59}$ And considerable difficulty was experienced in determining whether a Texas wife had a half interest in life insurance policies purchased out of communal funds or the husband had full ownership and power of transfer. ${ }^{80}$

Internal Revenue Code section 1000 (d), as amended by the Revenue Act of 1942, section 453, provides that "all gifts of property held as community property under the law of any State, Territory, or possession of the United States, or any foreign country shall be considered to be gifts of the husband, except that gifts of such property as may be shown to have been received as compensation for personal services actually rendered by the wife or derived originally from such compensation or from separate property of the wife shall be considered to be gifts of the wife." ${ }^{11}$ Under this provision, which applies only to gifts in 1943 and subsequent years, if community property is given away the husband is treated as owner and is taxed on the whole gift. If, however, no gift is made and the wife died, she is treated as owner and is taxed always on at least her half.

Under Regulations 108, section 86.2(3) spouses may change their

58 Recall that community property does not include that acquired by "gift, devise, or descent". Thus property so acquired will not be treated as community property when a gift is made. Virgil D. Gianninni (1943) 2 T. C. 1160. And if husband or wife gives community property to the other it ceases to be communal property.

69 Gillis v. Welch (C.C.A. 9th, 1935) 80 F. (2d) 165, cert. dert., (1936) 297 U. S. 722.

60 Blaffer v. Comm'r (C.C.A. 5th, 1939) 103 F. (2d) 489, cert. den., (1939) 308 U.S. 559, reh'g dent, (1939) 308 U.S. 635; Farish v. Comm'r (C.C.A. 5th, 1939) 103 F. (2d) 1007, cert.den., (1939) 308 U.S. 559; Joe J..Parkens (1943) 1 T. C. 982.

61 I. R. C. $\$ 1000$ (d), as amended by Revenue Act of $1942 \S 453$. 
separate property into community property without the payment of any gift tax ${ }^{62}$ This provision may have additional importance in California in changing community property acquired prior to July 29, 1927 into community property in which the wife is recognized as having a present, existing and equal interest. ${ }^{63}$

It has been suggested that the wife may release her interest in community property which was not received or derived from her earnings or from her separate property without the payment of any gift tax and that the interest so released will not be included in the wife's gross estate though released in contemplation of her death. ${ }^{\text {at }}$ This suggestion is based upon the language of Regulations 108, section 86.2.65 But transfers which might otherwise escape tax may run afoul of Internal Revenue Code section 1002 which was intended to reach transfers not coming within the common law concept of "gift" but which were made without an adequate and full consideration. The above suggestion does not take sufficient cognizance of this provision. By a conversion to joint tenancy the wife gets the community property freed of the husband's community right of management and control. At the same time, the husband receives his wife's release of her interest in the community property. Altman determines that the excess of the transfer by the husband over the consideration which he receives is the right to manage and control the property. ${ }^{66}$ The

62 U. S. Treas. Reg. 105, § 81.22.

63 Taylor, loc. cit. supra note 56.

64 Ibid. at 114.

65 "During the calendar year 1943 and any calendar year thereafter any gift of property held as community property ... constitutes a gift of the husband for the purpose of the gift tax statute (regardless of whether under the terms of the transfer the husband alone or the wife alone is designated as the donor or whether both are so designated as donors), except to the extent that such property is shown (1) to bave been received as compensation for personal services actually rendered by the wife or derived originally from such compensation, or (2) to have been derived originally from separate property of the wife.

"The rule stated in the preceding paragraph applies alike to a transfer by way of gift of community property to a third party or third parties, to a division of such community property between husband and wife into the separate property of each, and to a transfer by the husband and wife of any part of such community property into the separate property either of the luusband or of the wife, or into a joint estate or tenancy by the entirety of both spouses. In all of such cases the value of the property so transferred or so divided, as the case may be, is a gift by the husband to the extent that it exceeds the aggregate amount of the value of that portion which is shown to be economically attributable to the wife ... and of the value of the husband's interest in such property after such transfer or division."

66 Altman, Community Property and the Gift Tax (1943) 21 TAx Mag. 429. 
problem then arises of determining the value of this right of management and control. A Treasury Decision of February 20, 1943 provides that such a conversion is not such a transfer "as will incur the stamp tax as imposed by $\$ \$ 1802$ (b) and 3482," since under both community property ownership and tenancy in common, the spouses have "an undivided equal interest in the property." ${ }^{6 r}$ Yet in 1945 it was held that a gift resulted when a California husband and wife transferred shares held by them as community property to the wife as her separate property in consideration of her release of her community interest in a like number of shares of the same stock. ${ }^{\text {ss }}$

Under the present federal tax provisions it appears that different attributes of the community property system determine how the income, estate, and gift taxes, respectively, are to be levied.

For income tax purposes, ownership of the community property is the basis of taxation. Hence each spouse in a community property state may make a separate return on one-half of the community income.

The present estate and gift tax provisions do not appear to tax ownership, but rather tax the power of managing, controlling, and disposing of community property. The husband is uniformly found to be the manager of the community property in all the community property states. Except for such part of the community property as may be shown to have been received as compensation for personal services actually rendered by the wife or derived originally from such compensation or from her separate property (a very difficult proof to effectuate), all the community property should be included as the husband's for estate and gift tax purposes.

\section{CONCLUSIONS}

To avoid double taxation, the fact that the wife has power of testamentary disposition in most of the community property states of one-half of the community property, ${ }^{69}$ should not be made the basis for including in her estate tax one-half of the community property.

\section{Ibid. at 431 .}

68 Horst v. Comm'r (C. C.A. 9th, 1945) 150 F. (2d) 1, aff'g (1944) 3 T. C. 417. Cf. Fish v. Helvering (App. D.C. 1934) 75 F. (2d) 769, aff'g (1933) 27 B.T. A. 1002.

69 Ariz. Code Ann. (1939) \$39-109; Cal. Prob. Code \$201; Idaho Code AnN. (1932) § 14-113; LA. Civ. CODE (Dart, 1945) arts. 2406, 2409, 2430; WasH. Conrp. Stat. (Remington, 1922) \$1342. NEv. CoMp. Laws (Hillyer, 1929) \$3364 and N. M. Stat. (1941) \&31-108 provide that upon the wife's death the entire community property belongs without administration, to the surviving husband except where he has abandoned her. See also TEx. Stat. (Vernon, 1942) art. 2578. 
It is submitted that Congress should modify the last sentence of section $811(\mathrm{e})(2)$ of the Internal Revenue Code: "In no case shall such interest included in the gross estate of the decedent be less than the value of such part of the community property as was subject to the decedent's power of testamentary disposition" either by omitting the provision altogether or by making it apply only when double taxation would not result. Another solution for the problem might be for the legislatures of the community property states to adopt statutes similar to those now found in Nevada and New Mexico which provide that upon the wife's death the entire community property belongs, without administration, to the surviving husband. If the wife has no power of testamentary disposition of the community property, section $811(\mathrm{e})(2)$ should not subject her to an estate tax on the community property. 